\author{
S.N. Shaltakov ${ }^{1}$, S.Sh. Kazhikenova ${ }^{2}$, B.R. Nussupbekov ${ }^{1}$, \\ D.Zh. Karabekova ${ }^{1}$, A.K. Khassenov ${ }^{1}$, M. Stoev ${ }^{3}$ \\ ${ }^{I}$ Ye.A. Buketov Karaganda State University, Kazakhstan; \\ ${ }^{2}$ Karaganda Technical University, Kazakhstan; \\ ${ }^{3}$ Neofit Rilski South-West University, Bulgaria \\ (E-mail:sagyndyk613@mail.ru)
}

\title{
Mathematical model of high-temperature melt flow with account for short-range order nature
}

\begin{abstract}
The problems of mathematical description of the viscous motion of the metal melt accompanied by overcoming the internal friction caused by the movement of particles and overcoming the forces of their interaction are investigated. Solutions of hydrodynamic equations involving quantum potentials of interparticle interaction of atoms in melts, and quantum effects were taken into account using correlation functions of transport coefficients such as viscosity, since they are quite closely related to the structure of matter and are the most structurally sensitive characteristics of matter. The research consists in the fact that the correlation functions of viscosity are justified from the point of view of the quantum statistical method. The correlation between correlation functions and radial distribution functions is established. A mathematical model of the flow of high-temperature melts taking into account the nature of the near order in them and the account of the second coefficient of viscosity by methods of statistical physics is described. On the basis of theoretical studies the parameters determining the relationship between viscosity and interatomic potential are calculated. The found dependences allow us to determine the average values of any physical parameters, in particular, the values of shear and volumetric viscosity.
\end{abstract}

Keywords: viscosity, potential, hydrodynamic equations, computer simulation, melt.

\section{Introduction}

The authors have considered the problem of solving hydrodynamic equations involving quantum potentials of the interparticle interaction of atoms in melts, and quantum effects are taken into account using the correlation functions of transfer coefficients such as viscosity, since they are rather closely related to the structure of the substance and are the most structurally sensitive characteristic of the substance. Based on extensive classical studies of A.R. Regel, V.M. Glazov [1] it can be stated that metal and semiconductor melts are spatially inhomogeneous. The spatial heterogeneity is determined by their atomic-molecular character. Therefore, the physicochemical, metallurgical properties of metal and semiconductor melts should be described taking into account the short-range order. The methods of quantum statistical physics permit to express the coefficients of shear and volume viscosities using correlation functions [1,2].

\section{Experimental Part and Results Discussion}

One of the most constructive methods for studying the physical properties of melts is computer modeling [3-5]. Consider one of the options for splitting the equations of hydrodynamics $[6,7]$ as applied to the calculation of the melt flow in a flat channel in accordance with Figure 1.

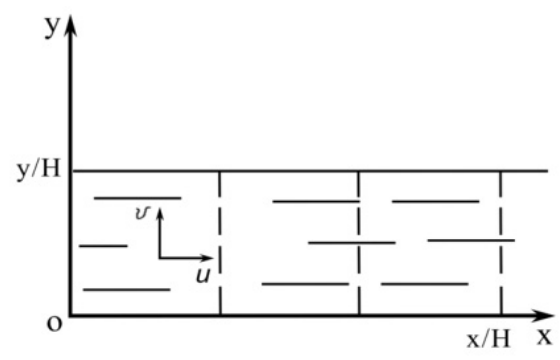

Figure 1. Model of melt flow in a flat channel 
Such a melt flow can be described by the following equations of dimensionless form:

$$
\begin{gathered}
\frac{\partial u}{\partial x}+\frac{\partial v}{\partial y}=0 \\
\frac{\partial u}{\partial t}+\frac{\partial u^{2}}{\partial x}+\frac{\partial u v}{\partial y}+\frac{\partial p}{\partial x}=\frac{1}{\operatorname{Re}}\left(\frac{\partial^{2} u}{\partial x^{2}}+\frac{\partial^{2} u}{\partial y^{2}}\right), \\
\frac{\partial v}{\partial t}+\frac{\partial v^{2}}{\partial y}+\frac{\partial u v}{\partial x}+\frac{\partial p}{\partial y}=\frac{1}{\operatorname{Re}}\left(\frac{\partial^{2} v}{\partial x^{2}}+\frac{\partial^{2} v}{\partial y^{2}}\right)
\end{gathered}
$$

where $\operatorname{Re}=\rho u_{0} H / \mu, H$ is a channel width; $u_{0}$ is speed; $\rho$ is density; $\mu$ is viscosity.

Equations (1)-(3) are integrated under the following initial and boundary conditions:

$$
\begin{array}{ll}
\text { at } t=0,0 \leq x \leq \frac{\ell}{H}, 0 \leq y \leq 1: & u=1, v=0, p=p_{0}, \\
\text { at } t>0, x=0,0 \leq y \leq 1: & u=0, v=0, p=p_{0}, \\
\text { at } t>0, x=\frac{L}{H}, 0 \leq y \leq 1: & \frac{\partial u}{\partial x}=\frac{\partial v}{\partial x}=0, \frac{\partial p}{\partial x}=-\beta, \\
\text { at } t>0, y=0, y=1,0 \leq x \leq \frac{L}{H}: & u=0, v=0, \frac{\partial p}{\partial y}=\frac{1}{\operatorname{Re}} \frac{\partial^{2} v}{\partial y^{2}},
\end{array}
$$

where $\beta$ is the preset pressure gradient; $\ell$ is the distance from the entrance to the ledge; $L$ is the total length of the channel.

Equations (1)-(3) depend on $t$ and can be solved for $u, v$. But the pressure $p$ is implicitly preset, because it is not part of the equations in the form of the derivative of $t$. To exclude this, we write the equation of continuity (1) as follows

$$
\frac{\partial w}{\partial t}+\frac{\partial u}{\partial x}+\frac{\partial v}{\partial y}=0, \text { where } w=p+\frac{1}{2}\left(v^{2}+u^{2}\right), \text { according to Bernoulli's law. }
$$

Then equations (1)-(3) can be reduced to the following two independent systems of equations (4) and (5), which are given for consideration below:

$$
\begin{aligned}
& \left\{\begin{array}{l}
\frac{1}{2} \frac{\partial w_{1}}{\partial t}+\frac{\partial u}{\partial x}=0 \\
\frac{1}{2} \frac{\partial u}{\partial t}+\frac{\partial u^{2}}{\partial x}+\frac{\partial p}{\partial x}=\frac{1}{\operatorname{Re}} \frac{\partial^{2} u}{\partial x^{2}} \\
\frac{1}{2} \frac{\partial v}{\partial t}+\frac{\partial u v}{\partial x}=\frac{1}{\operatorname{Re}} \frac{\partial^{2} v}{\partial x^{2}}
\end{array}\right. \\
& \left\{\begin{array}{l}
\frac{1}{2} \frac{\partial w_{2}}{\partial t}+\frac{\partial v}{\partial y}=0 \\
\frac{1}{2} \frac{\partial v}{\partial t}+\frac{\partial v^{2}}{\partial y}+\frac{\partial p}{\partial y}=\frac{1}{\operatorname{Re}} \frac{\partial^{2} v}{\partial y^{2}} \\
\frac{1}{2} \frac{\partial u}{\partial t}+\frac{\partial u v}{\partial y}=\frac{1}{\operatorname{Re}} \frac{\partial^{2} u}{\partial y^{2}},
\end{array}\right.
\end{aligned}
$$

where $w_{1}=p+\frac{u^{2}}{2}, w_{2}=p+\frac{v^{2}}{2}$.

Thus, these two systems of equations make it possible to model the melt flow in a flat channel. It should be noted that boundary conditions should also be split here. We represent the split boundary conditions for our case. For the system (4):

$$
\begin{gathered}
\text { at } x=0: u=1, v=0, p=0, \text { for } y, \text { at } x=\frac{L}{H}: \frac{\partial u}{\partial x}=\frac{\partial v}{\partial x}=0, \frac{\partial p}{\partial x}=-\beta, \text { for } y, \\
\text { at } x=\frac{\ell}{H}: u=0, v=0, \frac{\partial p}{\partial x}=\frac{1}{\operatorname{Re}} \frac{\partial^{2} u}{\partial x^{2}}, \text { for } 0 \leq y \leq \frac{L}{H} .
\end{gathered}
$$


For the system (5):

$$
\begin{aligned}
& \text { at } y=\frac{L}{H}, 0 \leq x \leq \frac{\ell}{H}: \quad u=0, v=0, \frac{\partial p}{\partial y}=\frac{1}{\operatorname{Re}} \frac{\partial^{2} v}{\partial y^{2}}, \\
& \text { at } y=0, \frac{\ell}{H} \leq x \leq \frac{L}{H}: \quad u=0, v=0, \frac{\partial p}{\partial y}=\frac{1}{\operatorname{Re}} \frac{\partial^{2} v}{\partial y^{2}}, \\
& \text { at } y=1,0 \leq x \leq \frac{L}{H}: \quad u=0, v=0, \frac{\partial p}{\partial y}=\frac{1}{\operatorname{Re}} \frac{\partial^{2} v}{\partial y^{2}} .
\end{aligned}
$$

Now consider the melt flow in a tilting trunk. For a particular design, one can interpret and write it as follows. Direct $O z$ axis along the axis of the trunk, assuming that the design of the trunk is infinitely long, and the melt flow is directed along the axis of the trunk so that only $w$, of the three components $u, v, w$, remains, therefore $u=0, v=0$. Let the melt flow be isothermal, then $\rho$ density and viscosity $\mu=$ const.

Consequently, the hydrodynamics equation can be written as:

$$
-\frac{1}{\rho} \frac{\partial p}{\partial x}=0,-\frac{1}{\rho} \frac{\partial p}{\partial y}=0, w \frac{\partial w}{\partial z}=-\frac{1}{\rho} \frac{\partial p}{\partial z}+\gamma\left(\frac{\partial^{2} w}{\partial x^{2}}+\frac{\partial^{2} w}{\partial y^{2}}+\frac{\partial^{2} w}{\partial z^{2}}\right), \frac{\partial w}{\partial z}=0 .
$$

Thus, as can be seen from the system of equations (6), the rate $w$ is a function of $x, y$, only; in addition, the pressure function $p$ is a function of $z$. On the basis of (6), we obtain the equation:

$$
\frac{d p}{d z}=\mu\left(\frac{\partial^{2} w}{\partial x^{2}}+\frac{\partial^{2} w}{\partial y^{2}}\right)
$$

The right side of (7) represents a function of $x, y$, while the left side is a function of $z$. From the basic principles of hydrodynamics, it follows that $\frac{d p}{d z}=-\frac{\Delta p}{\ell}$, where $\Delta p$ is the pressure drop at an arbitrarily chosen section; $\ell$ is the length of the trunk. In addition, due to the free surface of the melt, the pressure in the channel is equal to the atmospheric pressure [8]. Since the trunk is inclined to the horizon at a certain angle $\alpha$, a volume force arises, the projection of which on the axis $O z$ is equal to $F_{z}=g \sin \alpha=\frac{\Delta p}{\ell}$. Then the equation of motion (7) in the direction of $\mathrm{Oz}$ becomes:

$$
\mu\left(\frac{\partial^{2} w}{\partial x^{2}}+\frac{\partial^{2} w}{\partial y^{2}}\right)+\rho g \sin \alpha=0
$$

To solve the resulting equation, boundary conditions are necessary. These conditions will be determined by sticking of the melt to the bottom of the trunk and the absence of friction on the free surface of the melt. Denote the depth of the flow as $h_{1}$, and the width of the trunk as $h_{2}$. Then the boundary conditions of the problem can be written as follows:

$$
w=0 \text { at } y=0, \frac{\partial w}{\partial y}=0 \text { at } y=h_{1}, \frac{\partial w}{\partial x}=0 \text { at } x=h_{2} .
$$

Thus, equation (8) with boundary conditions (9) will describe the process of melt flow in specific designs of the trunk type. This model is designed for the melting equipment of the SCR-2000 line; the drawing of the lower trunk section is presented in Figure 2.

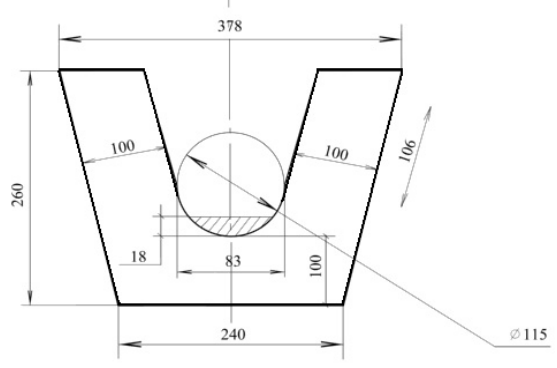

Figure 2. Lower trunk cross section 
Calculations are made for the lower trunk with an inclination angle of $3^{\circ}$. Numerical parameters are found by the following calculations: the area of the segment $S=\frac{[l r-a(r-h)]}{2}, a=83 \mathrm{~mm}, h=18 \mathrm{~mm}$, $l \approx \sqrt{a^{2}+\left(16 h^{2} / 3\right)}=\sqrt{83^{2}+\left(16 \cdot 18^{2} / 3\right)}=92.8 \mathrm{~mm}$, where $l$ is the length of the arc; $a$ is a chord; $h$ is a segment arrow. Consequently, $S=\frac{\left[92.8 \cdot \frac{115}{2}-83\left(\frac{115}{2}-18\right)\right]}{2}=1029 \mathrm{~mm}^{2}$. Then the melt consumption per second is $Q=3.61 \mathrm{~kg} / \mathrm{s}$. Based on this, one can make definite the average melt flow rate, which is equal to $v_{a v}=0.45 \mathrm{~m} / \mathrm{s}$.

In the calculations, constant step-sizes were used. The time-step in the calculations was chosen to be $\Delta t=0.001$. The found out results for the profiles of melt flow rates $v$ and $u$ in the flat channel are respectively presented in Figure 3. Obtaining the steady-state flow required 3000 steps. The results show that the proposed computational scheme is quite economical and it can be easily used to calculate the flow at sufficiently low Reynolds numbers. The analysis of the data obtained shows that replacing the continuity condition by a Poisson-type pressure equation leads to a numerical scheme that is free from a complicated computational procedure.
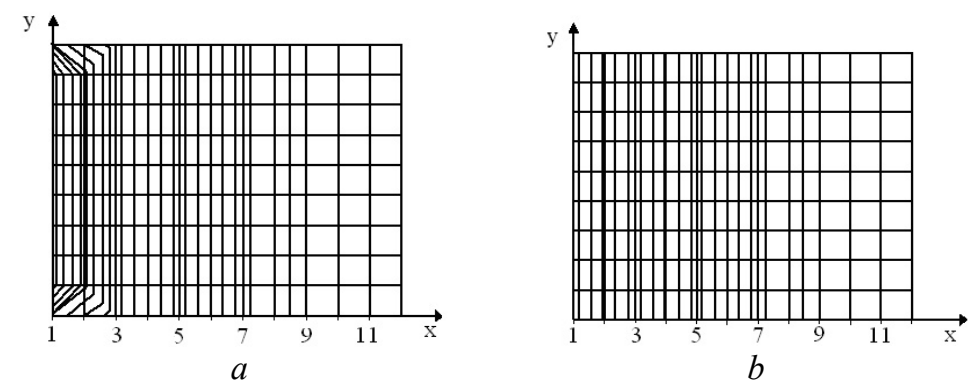

Figure 3. Profiles of a) transverse $v$ and b) longitudinal $u$ rates

On the basis of the compressibility sum rule, one can determine how self-consistent the adopted model of the melt system is. If the value of the volume modulus is determined correctly, then its reciprocal value is equal to compressibility. Compressibility is important when considering the physicochemical properties of molten metals. On the basis of [9], one may state that in a crystalline substance the bulk modulus of elasticity is equal to the derivative of the energy in terms of volume. At the same time, the static modulus must be consistent with the dynamic modulus. The dynamic modulus is calculated from the phonon dispersion ratio in the long wave approximation. Therefore, it is strongly linked by interatomic interaction. This statement is the essence of the compressibility rule and is well tested for crystalline metals [9]. Further studies have shown that the sum rule is not fully satisfied for the model of metals constructed using perturbation theory in the second order in empirical potentials. Then, the third and fourth order terms appearing in the dynamic matrix at $q \rightarrow 0$ bring to a second order contribution. Also, the discrepancy is obtained due to the inclusion of these contributions only when calculating static modules and neglecting them when calculating dynamic ones. The inclusion of the higher terms of the expansion in the construction of a dynamic matrix approximates the experimental data to the theoretical ones [10-12].

The data are in good agreement with experimental ones within $10 \%$. These assumptions make it possible to estimate the relaxation time of the structural viscosity (i.e. the volume one). According to Ya.I. Frenkel, the settled life of an atom $t=10^{-11} \mathrm{c}$. This value agrees well with the found relaxation time of the volume viscosity. According to the hole theory, it can be assumed that the volume deformation of the melt consists of two types of deformation. The first is instantaneous and retarding. The second is the deformation associated with the change in the number of holes during the movement of the melt. The retarding part of compressibility can be calculated by the formula $\beta_{3}=\frac{\Delta V^{2}}{V R T} e^{-\Delta H / R T}$, where $\Delta V$ is the change in the volume of holes, $\Delta H$ is the increase in enthalpy due to the formation of holes. Then, if the retarding part of 
compressibility is known, using the formula given in [11], it is possible to determine the value of the volume viscosity $\mu_{V}=\frac{t}{\beta_{0}}$, where $\beta_{0}$ is the equilibrium compressibility, $t$ is the lag time. The regime of the copper melt flow is completely determined by the melt viscosity, the theoretical and experimental [12] values of which are presented in Figure 4 and Table.

$\mathrm{T}$ a b l e

Experimental $\mu_{S E}$ and theoretical $\mu_{S T}$ values of the shear viscosity and the theoretical value of the volume viscosity $\mu_{V}$

\begin{tabular}{|c|c|c|c|}
\hline$T, \mathrm{~K}$ & $\mu_{S E}, P a \cdot s$ & $\mu_{S T}, P a \cdot s$ & $\mu_{V}, P a \cdot s$ \\
\hline 1358 & 0.005 & 0.0060999 & 0.12354 \\
\hline 1398 & 0.0046 & 0.005847 & 0.11959 \\
\hline 1438 & 0.0042 & 0.005606 & 0.11578 \\
\hline 1478 & 0.0038 & 0.005374 & 0.11208 \\
\hline 1518 & 0.0036 & 0.005153 & 0.10851 \\
\hline 1558 & 0.0033 & 0.00494 & 0.10505 \\
\hline 1598 & 0.0031 & 0.004736 & 0.09846 \\
\hline
\end{tabular}
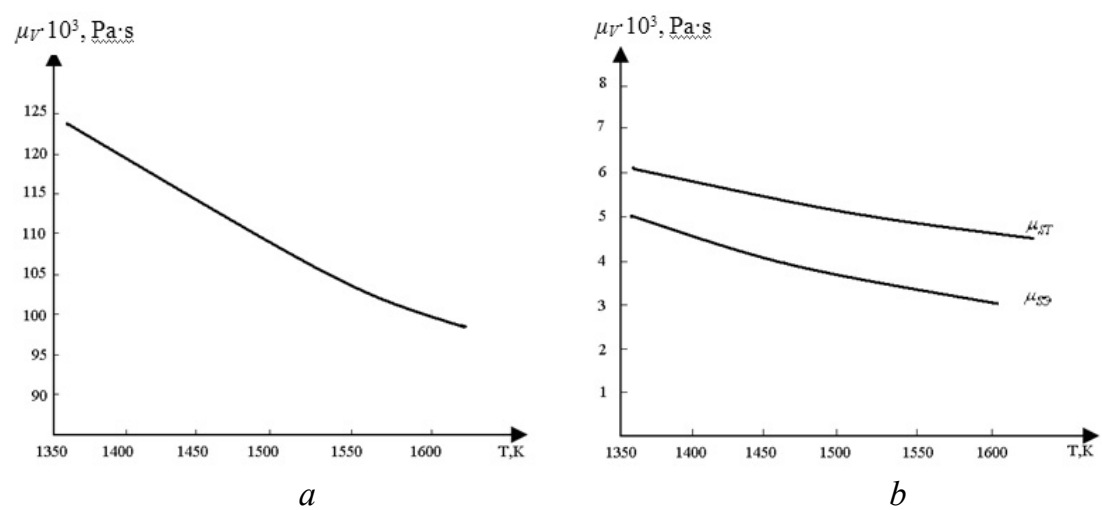

Figure 4. $a$ - the theoretical value of volume viscosity and $b$ - the experimental one $\mu_{S E}$ [9] and the theoretical value of shear viscosity $\mu_{S T}$

\section{Conclusions}

Thus, the main problem of the mathematical description of a viscous motion of a metal melt, accompanied by overcoming internal friction caused by the melt particles movement and overcoming the forces of their interaction, is considered. Based on the cluster theory of the melt flow, a relationship between viscosity and interatomic potential is established.

\section{References}

1 Регель А.Р. Физические свойства электронных расплавов / А.Р. Регель, В.М. Глазов. — М.: Наука, 1980. — 296 с.

2 Anisimov V.I. First principles electronic structure calculation and simulation of the evolution of radiation defects in plutonium by the density functional theory and the molecular dynamics approach / V.I. Anisimov, V.V. Dremov, M.A. Korotin // The Physics of Metals Metallography. — 2013. - Vol. 114. - P. 1087-1122.

3 Kato Yasumasa. Finite-element method for three-dimensional incompressible viscous flow using simultaneous relaxation of velocity and Bernoulli function.1st report flow in a lid-driven cubic cavity at $\mathrm{Re}=5000$ / Kato Yasumasa, Tanahashi Takahico // Journal JSME international journal. — 1991. — Vol. 57, No. 540. — P. 2640-2647.

4 Kazhikenova S.Sh. Monitoring of Process Flow Diagrams in the Production of Ferrous Metals / S.Sh. Kazhikenova // Refractories and Industrial Ceramics. - 2016. - Vol. 57, No. 4. - P. 360-363.

5 Yan X. Wei L. Numerical Simulation of Meso-Micro Structure in Ni-Based Superalloy During Liquid Metal Cooling / Yan X. Wei L, Lei Yao, Xin Xue, Yanbin Wang, Gang Zhao, Juntao Li, Qingyan Xu // The Minerals, Metals \& Materials Series: Proceedings of the 4th World Congress on Integrated Computational Materials Engineering. — 2017. — P. $249-259$. 
6 Sciubba E. A variational derivation of the Navier-Stokes equations based on the energy destruction of the flow / E. Sciubba // J. Math. and Phys. Sci. - 1991. - Vol. 25, No. 1. — P. 61-68.

7 Кажикенова С.Ш. Физико-химические аспекты теории металлургических процессов / С.Ш. Кажикенова, С.Н. Шалтаков, А.З. Исагулов. — Караганда: Изд-во КарГТУ, 2010. - 257 с.

8 Максимов Е.В. Механика жидкостей, газов и сыпучей среды / Е.В. Максимов, А.К. Торговец. — Алматы: РИК, 1997. $-254 \mathrm{c}$.

9 Сулейменов Т. Квантово-химическая природа ближнего порядка в неупорядоченных системах: дис. ... д-ра хим. наук: 02.00.04 / Т. Сулейменов. — Караганда, 2004. - 191 с.

10 Назаренко В.И. Модель жидкого металла при температуре плавления / В.И. Назаренко, В.А. Полухин, Р.М. Белякова, В.Ф. Ухов // Металлофизика. — 1981. — № 5. - С. 122-126.

11 Lobodyuk, V.A. Crystal-structural features of pretransition phenomena and thermo elastic martens tic transformations in alloys of nonferrous metals / V.A. Lobodyuk, Y.N. Koval, V.G. Pushin // The Physics of Metals Metallography. — 2011, Vol. 111. — P. $165-189$.

12 Шпильрайн Э.Э. Исследование вязкости жидких металлов / Э.Э. Шпильрайн, В.А. Фомин, С.Н. Сковородько, Г.Ф. Сокол. - М.: Наука, 1983. - 244 с.

\author{
С.Н. Шалтаков, С.Ш. Кажикенова, Б.Р. Нусупбеков, \\ Д.Ж. Карабекова, А.К. Хасенов, М. Стоев
}

\title{
Жақын тәртіптің табиғатын есепке ала отырып балқыманың жоғары температуралы ағынының математикалық моделі
}

\begin{abstract}
Бөлшектердің қозғалысынан және олардың өзара әрекеттесуінің күшінен туындаған ішкі үйкелісті жеңумен қоса жүретін металл балқымасының тұтқыр қозғалысының математикалық сипаттамасы мәселелері зерттелді. Қорытпалардағы атомдардың үлестес өзара әрекеттесуінің кванттық потенциалдарының қатысуымен гидродинамикалық теңдеулерді шешу және кванттық әсерлер тұтқырлық сияқты тасымалдау коэффициенттерінің корреляциялық функцияларын пайдалана отырып зерттелді, олар заттың құрылымымен тығыз байланысты және заттың неғұрлым құрылымдық-сезімтал сипаттамалары болып табылады. Зерттеу тұтқырлықтың корреляциялық функциялары кванттық-статистикалық әдіс тұрғысынан негізделді. Корреляциялық функциялар мен радиалды үлестіру функциялары арасында корреляция орнатылған. Жоғары температуралы балқымалар ағынының математикалық моделі, оларда жақын тәртіптің табиғатын есепке ала отырып және статистикалық физика әдістерімен екінші тұтқырлықтың коэффициентін есепке алу сипатталған. Жүргізілген теориялық зерттеулер негізінде тұтқырлық пен атомаралық потенциал арасындағы байланысты анықтайтын параметрлер есептелді. Табылған тәуелділіктер кез келген физикалық параметрлердің, атап айтқанда, жылжу және көлемдік тұтқырлықтың мәндерінің орташа мәнін анықтауға мүмкіндік береді.
\end{abstract}

Кілm сөздер: тұтқырлық, потенциал, гидродинамикалық теңдеулер, компьютерлік модельдеу, балқымалар.

\author{
С.Н. Шалтаков, С.Ш. Кажикенова, Б.Р. Нусупбеков, \\ Д.Ж. Карабекова, А.К. Хасенов, М. Стоев
}

\section{Математическая модель высокотемпературного течения расплава с учетом природы ближнего порядка}

Исследованы проблемы математического описания вязкого движения металлического расплава, сопровождающегося преодолением внутреннего трения, вызванного движением частиц и преодолением сил их взаимодействия. Решения гидродинамических уравнений с участием квантовых потенциалов межчастичного взаимодействия атомов в расплавах и квантовые эффекты учитывались с использованием корреляционных функций коэффициентов переноса, таких как вязкость, поскольку они довольно тесно связаны со структурой вещества и являются наиболее структурно-чувствительными характеристиками вещества. Исследования заключались в том, что корреляционные функции вязкости обоснованы с точки зрения квантово-статистического метода. Установлена корреляция между корреляционными функциями и функциями радиального распределения. Описана математическая модель течения высокотемпературных расплавов с учетом природы ближнего порядка в них и второго коэффициента вязкости методами статистической физики. На основании проведенных теоретических исследований рассчитаны параметры, определяющие связь между вязкостью и межатомным потенциалом. Найденные зависимости позволяют определить средние значения любых физических параметров, в частности, значений сдвиговой и объемной вязкости.

Ключевые слова: вязкость, потенциал, гидродинамические уравнения, компьютерное моделирование, расплав. 


\section{References}

1 Regel, A.R., \& Glazov, V.M. (1980). Fizicheskie svoistva elektronnykh rasplavov [Physical properties of electron melts]. Moscow: Nauka [in Russian].

2 Anisimov, V.I., Dremov, V.V., \& Korotin, M.A. (2013). First principles electronic structure calculation and simulation of the evolution of radiation defects in plutonium by the density functional theory and the molecular dynamics approach. The Physics of Metals Metallography, 114, 1087-1122.

3 Kato Yasumasa, \& Tanahashi Takahico (1991). Finite-element method for three-dimensional incompressible viscous flow using simultaneous relaxation of velocity and Bernoulli function.1st report flow in a lid-driven cubic cavity at $\mathrm{Re}=5000$. Journal JSME international journal, 57, 540, 2640-2647.

4 Kazhikenova, S.Sh. (2016). Monitoring of process flow diagrams in the production of ferrous metals. Refractories and Industrial Ceramics, 57, 4, 360-363.

5 Yan X. Wei L, Lei Yao, Xin Xue, Yanbin Wang, Gang Zhao, Juntao Li, \& Qingyan Xu (2017). Numerical Simulation of Meso-Micro Structure in Ni-Based Superalloy During Liquid Metal Cooling. Proceedings from The Minerals, Metals \& Materials Series. The 4th World Congress on Integrated Computational Materials Engineering, 249-259.

6 Sciubba, E. (1991). A variational derivation of the Navier-Stokes equations based on the energy destruction of the flow. J. Math. and Phys. Sci., 25, 1, 61-68.

7 Kazhikenova, S.Sh., Shaltakov, S.N., \& Isagulov, A.Z. (2010). Fiziko-khimicheskie aspekty teorii metallurhicheskikh protsessov [Physico-chemical aspects of the theory of metallurgical processes]. Karaganda: KSTU Publishing House [in Russian].

8 Maksimov, E.V., \& Torgovets, A.K. (1997). Mekhanika zhidkostei, hazov i sypuchei sredy [Mechanics of liquids, gases and solids]. Almaty: RIK [in Russian].

9 Suleimenov, T. (2004). Kvantovo-khimicheskaia priroda blizhneho poriadka v neuporiadochennykh sistemakh [Quantumchemical nature of short-range order in disordered systems]. Doctor's thesis. Karaganda [in Russian].

10 Nazarenko, V.I., Polukhin, V.A., Belyakova, R.M., \& Ukhov, V.F. (1981). Model zhidkoho metalla pri temperature plavleniia [Model of liquid metal at melting point]. Metallofizika - Metal Physics, 5, 122-126 [in Russian].

11 Lobodyuk, V.A., Koval, Y.N., \& Pushin, V.G. (2011). Crystal-structural features of pretransition phenomena and thermo elastic martens tic transformations in alloys of nonferrous metals. The Physics of Metals Metallography, 111, $165-189$.

12 Spielrain, E.E., Fomin, V.A., Skovorodko, S.N., \& Sokol, G.F. (1983). Issledovanie viazkosti zhidkikh metallov [The study of liquid metals viscosity]. Moscow: Nauka [in Russian]. 